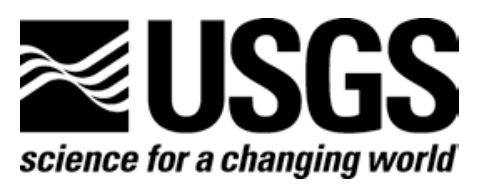

Prepared in cooperation with the Navajo Nation Minerals Department

\title{
Geologic Map of the Eastern Quarter of the Flagstaff 30' x 60' Quadrangle, Coconino County, Northern Arizona
}

Pamphlet to accompany

Scientific Investigations Map 3279 


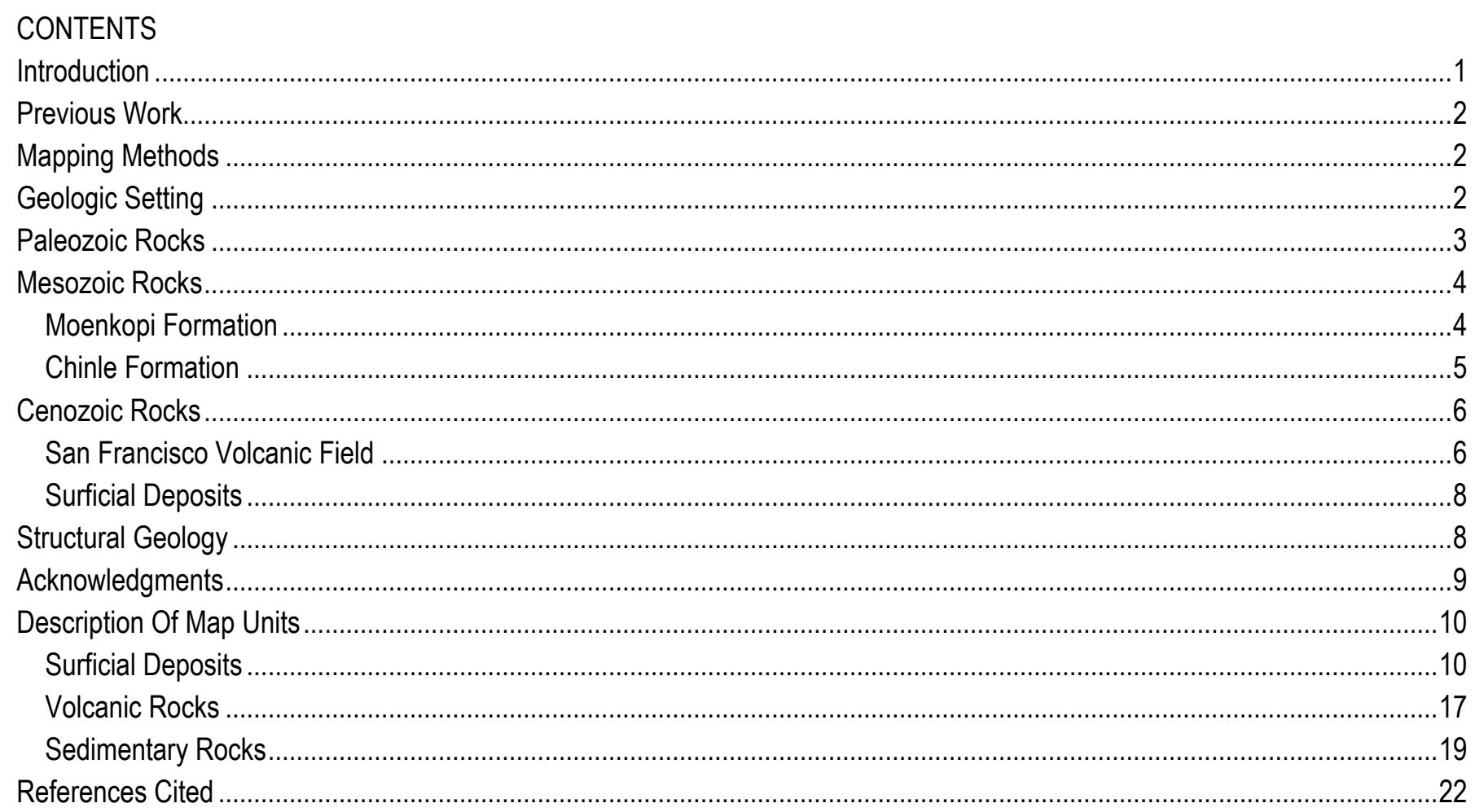




\title{
Geologic Map of the Eastern Quarter of the Flagstaff 30' x 60' Quadrangle, Coconino County, Northern Arizona
}

\author{
By George H. Billingsley, Debra Block, and Margaret Hiza Redsteer
}

\section{Introduction}

This geologic map is the product of a cooperative effort between the U.S. Geological Survey (USGS) and the Navajo Nation. It provides geologic information for resource management officials of the U.S. Forest Service, the Arizona Game and Fish Department, and the Navajo Nation Reservation (herein the Navajo Nation). Funding for the map was provided by the USGS geologic mapping program, Reston, Virginia. Field work on the Navajo Nation was conducted under a permit from the Navajo Nation Minerals Department. Any persons wishing to conduct geologic investigations on the Navajo Nation must first apply for, and receive, a permit from the Navajo Nation Minerals Department, P.O. Box 1910, Window Rock, Arizona 86515, telephone (928) 8716587.

The eastern quarter of the Flagstaff $30^{\prime}$ x 60' quadrangle includes eight USGS 1:24,000-scale quadrangles in Coconino County, northern Arizona (fig. 1, map sheet): Anderson Canyon, Babbitt Wash, Canyon Diablo, Grand Falls, Grand Falls SE, Grand Falls SW, Grand Falls NE, and Meteor Crater. The map is bounded by lat $35^{\circ}$ to $35^{\circ} 30^{\prime} \mathrm{N}$. and long $111^{\circ}$ to $111^{\circ} 15^{\prime} \mathrm{W}$. and is on the southern part of the Colorado Plateaus geologic province (herein Colorado Plateau). Elevations range from 4,320 $\mathrm{ft}(1,317 \mathrm{~m})$ at the Little Colorado River in the northwest corner of the map area to about $6,832 \mathrm{ft}(2,082 \mathrm{~m})$ at the southwest corner of the map.

Interstate 40 (I-40) provides access across the south-central part of the mapped area where north and south access roads lead from I-40 at the Buffalo Ranch Road Exit 225, Two Guns Exit 230, and Meteor Crater Road Exit 233 (formerly Rimmy Jim's Exit) that provides access south to Meteor Crater (fig. 2, map sheet) by a 6-mi-long (9.5-km-long) paved road (fig. 1, map sheet). Navajo Route 15 is a paved road in the northern part of the map area that provides limited access to the Navajo Nation, including a 9-mi-long (14.5-km-long) dirt road that leads north toward Grand Falls at the Little Colorado River (fig. 3, map sheet). The Little Colorado River crossing upstream of Grand Falls is not bridged and is impassable when the river is flowing.

Leupp, Arizona (originally Sunrise, Arizona), is the only community within the eastern quarter of the Flagstaff quadrangle (east-central edge). Larger communities, such as Winslow, Arizona, is $26 \mathrm{mi}(41.5 \mathrm{~km})$ east of the map on I-40, and Flagstaff, Arizona, is $27 \mathrm{mi}(37 \mathrm{~km})$ west of the map on I-40.

There are two prominent natural landmarks within the map: Meteor Crater (fig. 2, map sheet), a 600-ft-deep (183-m-deep) meteorite impact crater near the southeast corner of the map (Shoemaker and Kieffer, 1974; Kargel, 1998), and Grand Falls (fig. 3, map sheet), a 200-ft-high (60-m-high) waterfall (commonly dry) on the Little Colorado River in the northwest part of the map. Land management within the southern third of the map is a checkerboard square-mile pattern of private and 
State land; most of the private land belongs to the Hopi Tribe. The Buffalo Ranch is 1 mi south of the south-central edge of the map and is managed by the Arizona Game and Fish Department. Land in the northern two-thirds of the map is part of the Leupp Chapter of the Navajo Nation (fig. 1, map sheet). Coconino National Forest manages lands west, south, and southwest of the map margins.

This geologic map provides an updated geologic framework for the eastern quarter of the Flagstaff $30^{\prime}$ x $60^{\prime}$ quadrangle and is adjacent to two other recent geologic maps, the Cameron and Winslow 30' x 60' quadrangles (Billingsley and others, 2007, 2013).

\section{Previous Work}

An early reconnaissance photogeologic map (1:500,000 scale) of this area was compiled by Wilson and others (1969) as part of a geologic map of the State of Arizona. The state map was later recompiled at 1:1,000,000 scale by Richard and others (2000). An excellent photogeologic map of the Navajo Nation area was produced by Cooley and others (1969), but this product was not registered to a topographic base. Other maps that encompass the eastern quarter of the Flagstaff quadrangle include a regional geologic map of the Flagstaff $1^{\circ} \times 2^{\circ}$ quadrangle by Ulrich and others (1984) and a geologic map of the eastern San Francisco Volcanic Field by Moore and Wolfe $(1976,1987)$. A geologic map of the Cameron 30' x 60' quadrangle (Billingsley and others, 2007) adjoins the northern edge of this map; a geologic map of the Winslow 30' x 60' quadrangle (Billingsley and others, 2013) adjoins the eastern edge; and a geologic map of the Sedona $30^{\prime}$ x $60^{\prime}$ quadrangle (Weir and others, 1989) adjoins the southern edge. A geologic map of Meteor Crater was prepared by Shoemaker and Kieffer (1974) and the reader is referred to this publication for details of the geology in Meteor Crater. The surficial geologic map units of this map have been modified and updated to match surficial data of the adjacent Cameron and Winslow $30^{\prime}$ x $60^{\prime}$ quadrangles.

\section{Mapping Methods}

The geology was mapped using color 1:40,000-scale aerial photographs flown in 2005, followed by extensive field checking. Many of the Quaternary alluvial and eolian deposits have similar lithology and geomorphic characteristics and were mapped almost entirely by photogeologic methods. Lithology, stratigraphic position, and the amount of erosional degradation were used to determine relative age correlations of alluvial deposits. Geologic map units and structural features were field checked to ensure accuracy of location and description. Debra Block (U.S. Geological Survey) used ArcGIS to compile the digital database.

\section{Geologic Setting}

The map area is characterized by nearly flat lying to gently northeast dipping Paleozoic and Mesozoic rock strata that are partly covered by younger volcanic rocks along the western margin of the map area and by alluvium and eolian surficial deposits elsewhere, especially northeast of the Little Colorado River. The Pliocene and Pleistocene volcanic rocks of the San Francisco Volcanic Field form a protective caprock cover over soft Triassic strata of the Moenkopi Formation in the northwest quarter of the map. Remnants of a Miocene basalt flow forms a caprock over Triassic strata of the Chinle and Moenkopi Formations in the southwest corner of the map.

The Triassic strata in the Little Colorado River valley are mostly covered by Pleistocene and Holocene fluvial sand and gravel and eolian dune and sand-sheet deposits. The eolian deposits are commonly derived from the abundant fluvial sand along the Little Colorado River and tributaries that is transported northeasterly by seasonal southwesterly winds. 
The Little Colorado River was likely established as a tributary to the Colorado River in Grand Canyon about 6 million years ago (Ranney, 2005). The Little Colorado River in the northern part of the map lies within a strike valley that parallels the retreating gently northeast dipping Triassic strata of the Moenkopi and Chinle Formations. In some places, the river has eroded into the underlying resistant Permian strata of the Kaibab Formation. After the river or its tributaries encounter the Kaibab Formation, they become entrenched and trapped as canyon drainages into the Kaibab Formation. The Little Colorado River has eroded into the Kaibab Formation in the northwest quarter of the map and across the north-plunging Tolchico Anticline about $2 \mathrm{mi}(3 \mathrm{~km})$ upstream of Grand Falls. Several tributary drainages south and southwest of the Little Colorado River that meandered around on softer Triassic strata have been superimposed into the Kaibab Formation that preserved the meander patterns as small narrow meandering canyons (Padre Canyon, Anderson Canyon, Canyon Diablo, and others [fig. 1, map sheet]).

The Tertiary and Quaternary volcanic rocks of the San Francisco Volcanic Field are Miocene, Pliocene, and mostly Pleistocene age (Moore and others, 1974; Moore and Wolfe, 1976, 1987). The volcanic rocks range in composition from olivine-phyric basalt to calc-alkaline andesite and their relative age relations are based on magnetic polarity, isotopic composition, field relations, and a few K-Ar ages by Paul E. Damon and Edwin H. McKee (Ulrich and Bailey, 1987; Duffield and others, 2006; Damon and others, 1974). Basalt lava that reached the Little Colorado River and created Grand Falls is about $20 \mathrm{ka}(19.6 \pm 1.2 \mathrm{ka}$; Duffield and others, 2006).

\section{Paleozoic Rocks}

Neogene erosion of the highlands in the southwest two-thirds of the map area has exposed 150 to $250 \mathrm{ft}$ (46 to $76 \mathrm{~m}$ ) of the Kaibab Formation in Padre Canyon, Canyon Diablo, and Anderson Canyon. The Permian rocks are, in ascending order, the Toroweap Formation (includes the upper part of the Coconino Sandstone) and the Kaibab Formation. Limited exposures of the upper Coconino Sandstone are exposed in the walls of Meteor Crater (Shoemaker and Kieffer, 1974) and are included as part of the Toroweap Formation for this map. The Kaibab Formation and the upper part of the Toroweap Formation are exposed in the canyon of the Little Colorado River below Grand Falls (northwest corner of map) and in the walls of Meteor Crater. The Coconino Sandstone is not mapped herein because of the highly disrupted nature of the exposures in Meteor Crater and is included as part of the Toroweap Formation (for map details of Meteor Crater, see Shoemaker and Kieffer, 1974). The Kaibab Formation forms the surface bedrock for most of the southwestern two-thirds of the map except where covered by volcanic rocks, the Moenkopi Formation, or eolian and fluvial surficial deposits.

Beneath the Toroweap Formation, the Coconino Sandstone forms a white or yellowish-white crossbedded sandstone southeast of Winslow, Arizona, and is about $600 \mathrm{ft}(183 \mathrm{~m})$ thick in the subsurface of the map on the basis of well data (Bills and others, 2005). Subsurface well logs suggest that the basal part of the Coconino Sandstone is a fine-grained red sandstone that is likely the northern extent of the Permian Schnebly Hill Formation of the Verde Valley as defined by Blakey (1990) or the red De Chelly Sandstone exposed in the Defiance Plateau northeast of this map, because this map area lies approximately midway between the Defiance Plateau and the Verde River Valley (Blakey, 1996; Stanesco, 1991; Cooley and others, 1969).

The Coconino Sandstone and the basal Schnebly Hill Formation (or De Chelly Sandstone) form the local groundwater aquifer of this area known as the "C aquifer." The Coconino Sandstone gradually thins north, east, and west in the subsurface of the map and thickens to the south. The Schnebly Hill Formation thins north and west and gradually thickens south and southwest of the map 
and likely intertongues with the De Chelly Sandstone northeast of the map area (Blakey, 1996; Stanesco, 1991).

The upper part of the Toroweap Formation is exposed in the canyon of the Little Colorado River downstream of Grand Falls and forms a gray-brown cliff of calcareous sandstone. Similar but poor exposures of the Toroweap Formation are exposed in the walls of Meteor Crater. On the basis of local well-log records near Leupp, Arizona, (Bills and others, 2005) and exposures at the Little Colorado and Meteor Crater, the Toroweap Formation is about 30 to $50 \mathrm{ft}$ (9 to $15 \mathrm{~m}$ ) thick and thins eastward and thickens westward in the subsurface.

The Kaibab Formation is divided into the Harrisburg Member (upper part) and the Fossil Mountain Member (lower part) as defined by Sorauf and Billingsley (1991). The gradational boundary between the lower gray, cliff-forming, cherty, sandy limestone of the Fossil Mountain Member and the upper gray and reddish-yellow sandy limestone of the Harrisburg Member is difficult to distinguish in most places; therefore, these Kaibab members are collectively mapped as the Kaibab Formation.

\section{Mesozoic Rocks}

The erosion of the Little Colorado River and its tributaries exposed about $280 \mathrm{ft}(85 \mathrm{~m})$ of Triassic strata in the northeast third of the map. The Triassic rocks are, in ascending order, the Moenkopi Formation and the Chinle Formation.

A regional unconformity separates the Permian Kaibab Formation from the overlying Triassic Moenkopi Formation with an erosional relief typically less than $10 \mathrm{ft}(3 \mathrm{~m})$ across the north-central portion of the map. The unconformity is easily recognized by a color contrast between the gray-white Kaibab Formation and the red Moenkopi Formation. Shallow erosional depressions and channels eroded into the upper Kaibab Formation are filled with sandy detrital sediment that contains angular and subangular fragments of chert that are locally derived from the Kaibab Formation and form the basal part of the Moenkopi Formation in most areas.

\section{Moenkopi Formation}

Overlying the Kaibab Formation is a sequence of light-red sandstone ledges and dark-red siltstone slopes of the Moenkopi Formation. The Moenkopi Formation is preserved as isolated outcrops beneath Quaternary volcanic rocks along the northwest margins of the map and is extensively exposed diagonally across the northeastern part of the map area. The Moenkopi Formation, as much as $220 \mathrm{ft}(67 \mathrm{~m})$, once covered the entire area (McKee, 1954). An unknown amount of the upper Moenkopi Formation was removed by Triassic erosion prior to deposition of the overlying Chinle Formation.

The Moenkopi Formation is subdivided into three map units as defined by McKee (1954). In ascending order, they are the Wupatki Member, the lower massive sandstone member, and the undivided Moqui and Holbrook Sandstone Members.

The dark-red Wupatki Member of the Moenkopi Formation unconformably overlies the Kaibab Formation and thins diagonally southeastward from $75 \mathrm{ft}(23 \mathrm{~m})$ to $15 \mathrm{ft}(4.5 \mathrm{~m})$ thick and is locally absent in the southwest quarter of the map. The Wupatki Member gradually pinches out $8 \mathrm{mi}$ $(13 \mathrm{~km})$ east of the map where the lower massive sandstone member of the Moenkopi Formation unconformably overlies the Kaibab Formation. A lithologic and gradational contact separates the slope-forming Wupatki Member from the overlying cliff-forming lower massive sandstone member in most areas. 
The light-red, cliff-forming, lower massive sandstone member generally thins diagonally from northwest to southeast from about $40 \mathrm{ft}(12 \mathrm{~m})$ to less then $10 \mathrm{ft}(3 \mathrm{~m})$ thick. The lower massive sandstone member changes facies northwest of the map and correlates with the Shnabkaib Member of the Moenkopi Formation in northwestern Arizona (Billingsley and others, 2007).

The slope-forming Moqui Member is defined by McKee (1954) from exposures along Moqui Draw (Tucker Flat Wash today) $8 \mathrm{mi}(13 \mathrm{~km})$ west of Winslow near the eastern edge of the map and is $85 \mathrm{ft}(26 \mathrm{~m})$ thick and a lighter shade of reddish-brown then the underlying Wupatki or overlying Holbrook Member. The sandstone beds of the Holbrook Member of the Moenkopi Formation were originally defined by Hager (1922) and form an irregular line of bluffs along the Little Colorado River between Holbrook and Cameron, Arizona. The Holbrook and Moqui Members are mapped together as an undivided unit, because intertonguing and facies changes in some areas of the map make them difficult to separate. In general, the Moqui Member forms a uniform, mostly covered slope below the cliff-forming Holbrook Member. The sandstone beds of the Holbrook Member unconformably overlie the Moqui Member and commonly form interconnected, inverted riverchannel-ridge topography across the northeastern part of the map from Leupp to Winslow, Arizona. The Moqui and Holbrook Members are unconformably overlain by the Chinle Formation.

A regional uplift terminated the deposition of the marine tidal flats and river floodplain deposits that formed the Moenkopi Formation as that environment retreated northwestward into Utah, followed by a development of a new northwest-flowing drainage system (Blakey and Ranney, 2008). Drainages that eroded into the Moenkopi Formation averaged about $30 \mathrm{ft}(10 \mathrm{~m})$ deep and locally as much as $150 \mathrm{ft}(46 \mathrm{~m})$ deep. This unconformity is known as the Tr-3 unconformity (Blakey, 1994). The eroded stream valleys began accumulating mud, sand, and gravel that formed the overlying basal deposits of the Shinarump Member of the Chinle Formation.

\section{Chinle Formation}

The Chinle Formation is subdivided into three mappable units along the Little Colorado River valley in the northeast quarter of the map. In ascending order they are the Shinarump Member, the Petrified Forest Member, and the Owl Rock Member as defined by Repenning and others (1969).

The Shinarump Member includes an upper sandstone and siltstone member defined by Repenning and others (1969) in the Cameron area northwest of the map. It is predominantly a lenticular maze of thin to thick, interbedded, stream-channel and flood-plain deposits of light-brown, purple, gray, and red siltstone and sandstone that forms a transitional unit between the Shinarump Member and the overlying Petrified Forest Member of the Chinle Formation. Locally, this sandstone and siltstone member forms a minor and discontinuous, thin, upper part of the Shinarump Member and is herein mapped as the Shinarump Member.

The conglomeratic sandstone beds of the Shinarump Member contain numerous petrified log and wood fragments. Its thickness is variable owing to widespread channel erosion into the underlying Moenkopi Formation and is absent on local highland areas between channel valleys. The Shinarump Member is generally about 30 to $60 \mathrm{ft}$ (9 to $18 \mathrm{~m}$ ) thick along the Little Colorado River area northeast of Grand Falls. The contact between the Shinarump Member and the overlying Petrified Forest Member is gradational and highly variable, which reflects a lithologic and thickness change from ledges and slopes of brown and purple sandstone of the Shinarump Member to slopeforming, multicolored mudstone and siltstone of the Petrified Forest Member.

The Petrified Forest Member of the Chinle Formation forms the multicolored blue, red, and gray-green soft hills of the Painted Desert badlands along and northeast of the Little Colorado River. The Petrified Forest Member generally maintains a thickness between 400 and $500 \mathrm{ft}$ (122 and 153 $\mathrm{m})$ and was likely that thick in the southwestern half of the map before being removed by Cenozoic 
erosion. Much of the Shinarump Member and Petrified Forest Member are covered by fluvial deposits of the Little Colorado River floodplain, and sand from these fluvial deposits is transported northeastward by southwesterly winds that blanket most of the Petrified Forest and Shinarump Members. The Owl Rock Member of the Chinle Formation gradationally overlies the Petrified Forest Member and consists of about $270 \mathrm{ft}(82 \mathrm{~m})$ of gray, interbedded, ledge-forming, siliceous limestone and light-red calcareous siltstone that form the highland outcrops in the northeast corner of the map.

\section{Cenozoic Rocks}

\section{San Francisco Volcanic Field}

The oldest volcanic rocks of the San Francisco Volcanic Field within the map area are remnants of a Miocene basalt flow (Tb), on top of an unnamed butte in the southwest corner of the map, that came from Anderson Mesa about $4 \mathrm{mi}(6.5 \mathrm{~km})$ southwest of the map. This basalt flowed northeast down a stream channel eroded into the Shinarump Member of the Chinle Formation about 6 Ma (Damon and others, 1974) and now forms a protective caprock on soft Triassic sediments, creating an inverted drainage topography.

The Pleistocene basalt flows in the northwest quarter of the map came from several volcanoes west of the map that erupted about 800,000 to 19,000 years ago (K-Ar age, $0.786 \pm 0.14 \mathrm{Ma}$, $0.84 \pm 0.13 \mathrm{Ma}$, and $0.87 \pm 0.14 \mathrm{Ma}$; Damon and others, 1974). The age of the youngest basalt flow that helped form Grand Falls is $19.6 \pm 1.2 \mathrm{ka}$ as determined by four techniques: optical-luminescence, He surface exposure, ${ }^{40} \mathrm{Ar} /{ }^{39} \mathrm{Ar}$, and a Magnetic secular-variation match (Esser, 2003; Duffield and others, 2006).

The older basalt flows of Woodhouse age (about 0.8 to $3.0 \mathrm{Ma}$; Damon and others, 1974) as described by Ulrich and Bailey (1987) and Moore and Wolfe (1976) flowed northeast toward the Little Colorado River but stopped about $2 \mathrm{mi}(3 \mathrm{~km})$ south of today's river and formed a basalt caprock over strata of the Moenkopi Formation. These older basalt flows ( $Q b w)$ are collectively and informally called the basalt flows of Woodhouse Mesa (Wolfe and others, 1987). Woodhouse Mesa is located in Wupatki National Monument a few miles northwest of the map area. Younger volcanic eruptions just west of the map are the source of various basalt flows (Qbm1, Qbm2, Qbm, Qbr, Qb) shown on the northwest part of the map.

Pleistocene volcanic eruptions to the west built up prominent pyroclastic cones and produced several associated basalt flows that traveled northeastward down drainages towards the Little Colorado River. The basalt flows filled and blocked some drainages, allowing ponded sediments to accumulate behind the basalt dams and also deflect the local streams around the flow margins and into nearby lowland areas or other drainages. Two or more basalt flows reached the Little Colorado River at Grand Falls and one or more flows reached a now-abandoned reach of the Little Colorado River about $7 \mathrm{mi}(11 \mathrm{~km})$ upstream of Grand Falls on the east side of Tolchico Anticline.

The basalt flows that reached the Colorado River at Grand Falls flowed into and filled a 215ft-deep (65-m-deep) canyon of the Little Colorado River as it spread out northeastward from the canyon for a short distance, effectively forming a basalt dam of the river. This basalt also flowed down the river for approximately $21 \mathrm{mi}(33.5 \mathrm{~km})$ and about $10 \mathrm{mi}(16 \mathrm{~km})$ upstream of the basalt dam (Hanson and others, 2008). Upstream of the basalt dam, the Little Colorado River drainage filled with sediment that allowed the river to flow north around the basalt flow and over the north rim of the canyon forming today's 200-ft-high (60-m-high) Grand Falls (fig. 3, map sheet). This basalt flow likely came from a crater called "The Sproul" on the west side of Merriam Crater about $8 \mathrm{mi}(13 \mathrm{~km})$ 
southwest of Grand Falls (Hanson, 2009) and is mapped as The Sproul basalt flow of Merriam Crater (Qbm1).

A similar age basalt flow came from two vents on the east side of Merriam Crater that appears to have erupted simultaneously and is mapped as the east vent basalt flow of Merriam Crater (Qbm2). This flow traveled northeast toward the Little Colorado and appears to have stopped about a mile south of Grand Falls. Prior to The Sproul and east vent flows, a basalt flow from Merriam Crater (Qbm) flowed northeast toward the Little Colorado River and may have reached the river first, but younger subsequent flows from The Sproul and east vent of the Merriam Crater system appears to have overflowed the Merriam Crater flow (Qbm) at Grand Falls.

Approximately $7 \mathrm{mi}(11 \mathrm{~km})$ upstream of Grand Falls, the Little Colorado River was superimposed across the north-plunging Tolchico Anticline and eroded a 240-ft-deep (74-m-deep) canyon into the Kaibab Formation, herein referred to as "Tolchico canyon" for location purposes (fig. 4, map sheet). One or two basalt flows reached the Little Colorado River at the northeast flank of Tolchico Anticline and formed a basalt dam across the river. This basalt flow $(\mathrm{Qb})$ came down a tributary drainage from the vicinity of South Sheba Crater or Merrill Crater, just west of the map edge. These young flows have an extensive and thicker eolian cinder cover than the basalt flows at Grand Falls, suggesting a possible older age for the basalt flow and dam at Tolchico Canyon. The ${ }^{40} \mathrm{Ar} /{ }^{39} \mathrm{Ar}$ age of this flow and dam is $175 \mathrm{Ka}$ (Esser, 2003; Hanson and others, 2008).

The basalt dam of the Little Colorado River at Tolchico canyon produced a large shallow lake and floodplain upstream of the dam that deposited fine-grained silt and sand into and along the Little Colorado River where it parallels a northwest-oriented strike valley eroded into soft sediments of the Chinle Formation. Eventually, the Little Colorado River filled the lake, overflowed the north end of Tolchico Anticline, and flowed back to the original canyon about $2 \mathrm{mi}(3 \mathrm{~km})$ downstream of the basalt dam, subsequently eroding a more recent canyon through the Moenkopi and upper Kaibab Formations. Based on older and higher river-gravel deposits preserved above the Little Colorado River valley upstream and downstream of Grand Falls and Tolchico canyon, the basalt dam at Tolchico canyon is Pleistocene age.

The prevailing southwesterly winds during and since the pyroclastic eruptions southwest and west of the map have distributed thin to thick black cinder deposits over much of the bedrock surface within the northern map area. Only the thickest or most widespread deposits are shown as eolian cinder sand-sheet (Qsc), unconsolidated cinder-dune (Qdc1), consolidated cinder-dune (Qdc2), or mixed alluvium and eolian (Qae) deposits.

Black cinder deposits accumulated as falling dune deposits within a sharp meander bend of Padre Canyon (fig. 5, map sheet) that formed a cinder dune dam across the canyon about $2 \mathrm{mi}(3 \mathrm{~km})$ upstream of its junction with Canyon Diablo (west-central part of map; fig. 5, map sheet). The small lake that developed in Padre Canyon behind the cinder dune dam allowed ponded water to seep through open fractures in the Kaibab Formation through a narrow neck of the meander loop just upstream of the cinder dam. The open cracks and fractures quickly eroded a narrow slot canyon through the meander-loop neck. The cinder-dune-clogged meander loop was abandoned in favor of the narrow open-slot canyon. The cinder dune (Qdc2) accumulated to $180 \mathrm{ft}(55 \mathrm{~m})$ thick in the 260ft-deep (80-m-deep) canyon where it is preserved today as a consolidated cinder dune.

Black eolian cinder deposits also filled the abandoned 2-mi $(3-\mathrm{km})$ section of Tolchico canyon of the Little Colorado River downstream of the basalt dam (fig. 4, map sheet). The black eolian cinders were accumulated by southwesterly winds and transported over the south rim of the canyon to form deposits as much as $200 \mathrm{ft}(60 \mathrm{~m})$ thick in Tolchico canyon. These black consolidated cinder dunes (Qdc2) are well preserved in Tolchico canyon and in Padre Canyon (figs. 4, 5, map sheet). 


\section{Surficial Deposits}

A variety of fluvial stream and alluvial fan deposits of various ages and configurations are scattered throughout the map area. The Little Colorado River is the principal stream in the map and extensive ponded and flood-plain deposits have accumulated within its valley. The Little Colorado River channel and its flood plains have undergone extensive geomorphic reconfiguration as demonstrated by historic photographic records just upstream of this map in a report by Block and Redsteer (2011).

Terrace deposits of the older Little Colorado River are present at four stratigraphic levels above three younger floodplain deposits on both sides of the river in the northern quarter of the map. These river terraces $(\mathrm{Qg} 4, \mathrm{Qg} 5, \mathrm{Qg6}, \mathrm{Qg} 7)$ provide a glimpse into the Pleistocene development of the Little Colorado River and its valley. All older terrace deposits fill flat channel floors of the Little Colorado River, perhaps because of the overwhelming sediment load of the river. Both the channel floors and adjacent valley appear to have filled with thick river sediment, causing the river to meander broadly within its valley; subsequent erosion lowered the river to a new position, establishing a new river channel in bedrock, which then filled again with sediment. This cut-and-fill process appears to have repeated itself at least four times, possibly reflecting Pleistocene climate changes.

The alluvial deposits associated with the Little Colorado River and nearby tributaries provide an abundant supply of silt and sand that is subject to transportation by southwesterly winds that develop extensive eolian sand-sheet and dune (Qd, Qes, Qdl, Qdb) deposits northeast of the Little Colorado River. The eolian deposits are intermittently eroded by local fluvial erosion and sand and silt is transported back to the Little Colorado River where the eolian transport process repeats itself (Billingsley, 1987). Eventually, the sand is transported down the Little Colorado River to the Colorado River and through Grand Canyon. Eolian and fluvial activity commonly interact to form deposits from both processes, mixed alluvium and eolian (Qae) deposits, throughout the map area. Black volcanic cinders transported by southwesterly winds form extensive eolian cinder sand-sheets (Qsc) and local eolian cinder-dune (Qdc1, Qdc2) deposits.

Other surficial units include landslide (Ql) and talus and rockfall (Qtr) deposits in canyons of the Little Colorado River and tributary canyon drainages and extensively in the vicinity of the unnamed butte in the southwest corner of the map. Meteor Crater impact debris is generally localized to the vicinity of Meteor Crater. Several grabens and sinkholes have accumulated ponded sediments (Qps) as small intermittent lake deposits. These small lakes were likely an important intermittent water source for the prehistoric and historic inhabitants of the area. Manmade diversion dams, stock tanks, gravel pits, and quarries (Qaf) are mapped to illustrate the human impacts on the landscape. Not all road and pipeline construction excavations or deposits are shown.

\section{Structural Geology}

Paleozoic and Mesozoic strata within the map area have an average regional dip of about $1^{\circ}$ NE., except in the northeastern quarter of the map where strata dips as much as $4^{\circ} \mathrm{NE}$.. The landscape is gently folded by low-amplitude, alternating, northeast-plunging anticlines and synclines that are oriented north to south across the east-central part of the map. West of the gentle northeastplunging series of anticlines and synclines is a north-south-oriented, north-plunging anticline called Tolchico Anticline (Ulrich and others, 1984), which is the principal fold within the map area (fig. 1, map sheet). An unnamed northeast-dipping monocline is present in the southwest corner of the map with strata that dip between $4^{\circ}$ and $7^{\circ} \mathrm{NE}$. 
Compressional folding of Paleozoic and Mesozoic rocks began in Late Cretaceous and early Tertiary time (about $65 \mathrm{Ma}$ ). The Laramide erosional period began removing Mesozoic strata that once covered the entire map area (Huntoon, 2003). Today's landscape took shape during late Tertiary and Pleistocene time when the Little Colorado River drainage system developed. The Little Colorado River and its tributaries became firmly established and integrated with the Colorado River in the Grand Canyon about 5 to 6 Ma sometime during the late Miocene or early Pliocene (Lucchitta, 1990; Ranney, 2005).

The northeast dipping monocline in the southwest corner of the map likely overlies a deepseated reverse fault that displaced strata up-to-the-west during Late Cretaceous and early Tertiary time (Huntoon, 2003). During the Pliocene and Pleistocene time, northeast-southwest extension has reactivated the deep-seated fault, and some of the normal fault separations have reversed some of the Cretaceous and early Tertiary fold offset, as well as accentuating the dip of the monocline by reverse drag along the faults. Late Cenozoic extensional faulting produced many northwest-trending grabens beginning in late Pliocene time (less than $2.59 \mathrm{Ma}$ ) on the basis of similar extensional faulting evidence along the Hurricane and Toroweap Faults in the Grand Canyon region northwest of the map area (Billingsley and Workman, 2000; Billingsley and Wellmeyer, 2003; Billingsley and others, 2007).

The grabens and faults in the map area appear to be active on the basis of small separations of Pleistocene and Holocene alluvial deposits along faults and associated large open bedrock fissures (fig. 6, map sheet). A few sinkholes or open cracks that have developed along the fractures and joints associated with grabens and runoff in several minor drainages has been interrupted by recent bedrock open-crack fissures and sinkhole development along fractures. A small sinkhole has recently developed along a fracture fault in Big Anderson Tank, southwest quarter of map that now drains the reservoir of water.

The open bedrock fissures that align along regional joints and fractures may reflect a more recent tensional stress of the landscape (fig. 6, map sheet). Bedrock crack fissures as much as $500 \mathrm{ft}$ $(152 \mathrm{~m})$ deep have been explored northwest of the map at Wupatki National Monument (Peter Huntoon, oral commun., 2005). The northeasterly folds and associated joint and fractures and northwesterly joint and fracture sets have controlled the shape of Meteor Crater, which is somewhat square in outline (fig. 2, map sheet); the diagonals of this squarish area coincide with the trend of the two main sets of joints (Shoemaker and Kieffer, 1974).

\section{Acknowledgments}

The cooperation and support of the Navajo Nation Minerals Department and the Leupp Chapter of the Navajo Nation were very helpful in permitting the mapping of this part of the Navajo lands. We also appreciate advice, revisions, and suggestions from Wendell Duffield of Northern Arizona University, Flagstaff, Arizona; Lee Amoroso of the U.S, Geological Survey, Flagstaff, Arizona; and Charles L. Powell, II, and Jan Zigler of the U.S. Geological Survey, Menlo Park, California. 


\section{DESCRIPTION OF MAP UNITS}

\section{SURFICIAL DEPOSITS}

Surficial deposits are differentiated from one another chiefly on the basis of differences in morphologic character and physiographic position as observed on color 1:24,000-scale aerial photographs flown in 2005 and from field observations. Older alluvial and eolian deposits generally exhibit extensive erosion and have greater topographic relief, whereas younger deposits are either actively accumulating material or are moderately eroded. All surficial deposits have an approximate map contact (not dashed) with adjacent surficial deposits and bedrock outcrops.

Qaf Artificial fill and quarries (Holocene) - Alluvium and bedrock material excavated from borrow-pits and trenches to build livestock tanks, drainage diversion dams, roads, pipelines, and other man-made construction projects. Not all pipeline and highway/road excavations and landfills are mapped

Qs Stream-channel deposits (Holocene) - White to light-red and gray, poorly sorted interbedded silt, clay, sand, gravel, pebbles, cobbles, and small boulders. Most of the gravel, cobbles, and boulders are subrounded to round. Deposit intertongues with, overlaps, or is inset against other adjacent fluvial surficial deposits (Qa1, Qa2, Qv, Qg1, Qg2, Qf, Qf1, Qf2, Qf3, Qps, Qae). Stream channels subject to high-energy flows and flash-flood debris flows. Little or no vegetation in stream channels except for salt cedar (tamarisk), Russian olive, and cottonwood trees and desert shrubs along channel margins of Little Colorado River and larger tributaries such as Padre Canyon, Canyon Diablo, and Anderson Canyon. Unit often intertongues with other alluvial or eolian deposits, and contacts are gradational and approximate in the lateral and vertical sense. Streamchannel of Little Colorado River is mapped as shown on color 1:24,000scale aerial photographs flown in 2005. The river channel is subject to yearly change caused by flood events (Block and Redsteer, 2011). Thickness, 6 to $30 \mathrm{ft}$ (2 to $9 \mathrm{~m}$ ) or more

Modern flood-plain deposits (Holocene) - Gray, brown, and light-red clay, silt, sand, and some lenticular coarse gravel; partly consolidated by clay, gypsum, and calcite cement. Intertongue with or overlap other alluvial deposits (Qs, Qv, Qg1, Qa1). Inset into numerous fluvial or eolian surficial deposits along Little Colorado River and main tributary drainages. Similar to and often adjacent to valley-fill (Qv) deposits in shallow drainage valleys on plateau surface in southwestern half of map where broad, flat valleys are subject to widespread and frequent flooding. Support thick growth of sagebrush, grass, and small high-desert shrubs that help trap and accumulate fine-grained sediment on floodplains. Subject to temporary ponding and often mixed with ponded sediments (Qps) in small graben valleys. Thickness, 3 to $30 \mathrm{ft}$ (1 to $9 \mathrm{~m}$ )

Qps Ponded sediments (Holocene) - Gray, brown, or light-red clay, silt, and sand; includes lenses of intertonguing gravel composed locally of small isolated fragments or pebbles of chert, limestone, and sandstone; partly 
Qd Dune-sand and sand-sheet deposits (Holocene)-White to gray to light-red,

consolidated by clay, calcite, and (or) gypsum cement. Often adjacent to or on flood-plain (Qf, Qf1, Qf2, Qf3) deposits along Little Colorado River. Occupies manmade internal drainage depressions or natural depressions formed within extensive dune-sand or sand-sheet (Qd) areas. Desiccation cracks often develop in dry conditions on hardpan surfaces and clay content often restricts plant growth. Thickness, 5 to $40 \mathrm{ft}$ (1.5 to $12 \mathrm{~m}$ ) fine- to coarse-grained sand composed mainly of quartz, chert, minor feldspar grains and minor amounts of basaltic cinder fragments. Form small complex parabolic dunes, barchan dunes, and dome dunes mixed within extensive sand sheet deposits. Primary deposits are northeast of Little Colorado River and locally within tributary drainages northeast of Little Colorado River. Support moderate growth of grass, sagebrush, and various small desert shrubs. Thickness, 3 to $60 \mathrm{ft}$ (1 to $18 \mathrm{~m}$ )
Qes Young eolian sand-sheet deposits (Holocene) - White to gray, fine- to coarse- grained, windblown sand composed of quartz, chert, and minor feldspar grains, derived from Little Colorado River stream-channel (Qs) deposits northeast and east of Little Colorado River over gently sloping terrain. Include abundant basaltic cinder fragments southwest of Little Colorado River. Often intertongue with mixed alluvium and eolian (Qae) deposits. Support moderate growth of grass and small high-desert shrubs. Thickness, 1 to $15 \mathrm{ft}(0.3$ to $4.5 \mathrm{~m})$

Qdl Linear dune deposits (Holocene) - White, gray, and light-red, fine- to mediumgrained, well-sorted, quartz sand dunes that are aligned in general northeast direction; unconsolidated. Only two linear dunes are shown in northeast corner of map area, but they are common northeast of the map. Numerous thin, low-amplitude, and discontinuous linear dunes are too thin to show at map scale within large areas mapped as dune-sand and sand-sheet (Qd) deposits. Thickness, 6 to $20 \mathrm{ft}$ ( 2 to $6 \mathrm{~m}$ )

Qdp Parabolic dune deposits (Holocene) - White, gray, and light-red, fine- to medium-grained, well-sorted, unconsolidated quartz sand arranged into individual parabolic dunes but most commonly present as complex intertonguing parabolic dunes associated with extensive young eolian sandsheet (Qes) deposits just northeast of Little Colorado River. Small ponded sediments (Qps) commonly form in low internal-drainage areas within parabolic-dune complexes. Supports sparse grassy vegetation. Thickness, 6 to $20 \mathrm{ft}(2$ to $6 \mathrm{~m})$

Qdb Barchan dune and sand-sheet deposits (Holocene) - White, gray, light-red, fineto coarse-grained, well-sorted quartz sand and basaltic cinder fragments that form isolated barchan dunes northeast of Grand Falls and Little Colorado River. Subject to new distribution changes on yearly basis due to seasonal wind storms. Support little or no vegetation. Thickness, 3 to $8 \mathrm{ft}$ (1 to $2.4 \mathrm{~m}$ )

Qsc Eolian cinder sand-sheet deposits (Holocene) - Black, gray, and some red, fineto coarse-grained fragments of angular to subangular, glassy, basaltic cinder and scoria. Similar to unconsolidated cinder-dune (Qdc1) deposits 
but forms thin patchy or widespread wind-blown deposits over bedrock of Moenkopi Formation or Kaibab Formation in west-central part of map; forms discontinuous and thinner deposits in east-central part of map. Cinder fragments become smaller and more rounded farther downwind (northeast) across northern half of map area becoming mixed with quartz sand grains. Volcanic cinders are commonly present with mixed alluvium and eolian (Qae) deposits. Thickness, 1 to $5 \mathrm{ft}(0.3$ to $1.5 \mathrm{~m})$

Qdc1 Unconsolidated cinder-dune deposits (Holocene) - Black and gray fine- to coarse-grained angular to subangular fragments of glassy basaltic cinder and scoria. Material is partially derived from several volcanic vent eruptions just west and southwest of map, such as Merrill Crater and South Sheba Craters about 1 to $4 \mathrm{mi}(1.5$ to $6.5 \mathrm{~km})$ west of map. May include vesicular air-fall cinder ash deposits from other volcanic vents as far west as Sunset Crater, $12 \mathrm{mi}(19 \mathrm{~km})$ west of map area about 1,000 years ago (Hooten and others, 2001), where cinders were transported by southwesterly or westerly winds into map area. Deposits accumulate against or downslope of local topographic obstructions such as rough basalt flow surfaces, steep-walled drainages, and small fault-scarp ledges. Thickness, 3 to $10 \mathrm{ft}$ ( 1 to $9 \mathrm{~m}$ ) or more

Qdc2 Consolidated cinder-dune deposits (Holocene) - Black and gray, fine- to coarsegrained, angular to subangular fragments of glassy basaltic cinder ash. Unit is tightly compacted, well consolidated, and lightly cemented by silica and some calcite. Source of cinder ash is unknown but is wind-transported from several potential volcanic cone centers west and southwest of map. Deposits have been transported by southwesterly winds across surface of Kaibab Formation and accumulated as falling dune deposits in Tolchico canyon of the Little Colorado River (fig. 4, map sheet) and in Padre Canyon (fig. 5, map sheet). Thickness, 5 to $240 \mathrm{ft}$ (1.5 to $73 \mathrm{~m}$ )

Qa1 Young alluvial fan deposits (Holocene) - Gray, light-brown, and light-red mud, silt, and sand mixed with black cinders. Include cobbles and pebbles of chert, limestone, and sandstone locally derived from the Kaibab, Moenkopi, and Chinle Formations. Partly consolidated by gypsum and calcite cement. Intertongues or overlaps with various Quaternary surficial deposits (Qs, Qps, Qf1, Qf2, Qf3, Qes, Qd, Qv, Qg1, Qae). Surface subject to extensive sheet-wash erosion, flash-flood debris flows, and small arroyo erosion. Support light to moderate growth of sagebrush, camel thorn bush, salt bush, cactus, and grass. Thickness, 3 to $20 \mathrm{ft}$ (1 to $6 \mathrm{~m})$

Qg1 Young terrace-gravel deposits (Holocene) - Light-brown, pale-red, and gray, well-sorted, interbedded mud, silt, sand, black cinder sand, pebbles, cobbles, and some boulders; partly consolidated by matrix of mud and sand cemented by calcium carbonate and gypsum. Include subangular to wellrounded Paleozoic and Mesozoic sandstone, limestone, and chert clasts of local origin. Include some well-rounded clasts of quartzite, quartz, and assorted metamorphic crystalline rocks reworked from Tertiary conglomerates south of map area. Includes well-rounded volcanic clasts derived from San Francisco Volcanic Field in southwest part of map. Subject to flash-flood and sheet-wash erosion. Support little vegetation, 
mainly grass. Forms terraced benches about 3 to $12 \mathrm{ft}$ ( 1 to $3.6 \mathrm{~m}$ ) above stream-channel (Qs) deposits within narrow canyons in southwest twothirds of map. Thickness, 3 to $12 \mathrm{ft}$ (1 to $3.6 \mathrm{~m}$ )

Young flood-plain deposits (Holocene) - Gray-brown clay, silt, and fine- to coarse-grained sand; weakly consolidated by clay content. Forms benches 3 to $10 \mathrm{ft}$ above stream-channel (Qs) or modern flood-plain (Qf) deposits. Subject to cut-bank channel erosion along Little Colorado River and by local streams in flatland areas in southwestern two-thirds of map. Overlapped by thin accumulations of young surficial deposits (Qd, Qes, Qps, Qa1). Supports thick growths of salt cedar (tamarisk) trees, grass, tumbleweed, camel thorn bush, and various other high-desert shrubs. Often subjected to overbank flooding or channel erosion by Little Colorado River and local tributary streams. Thickness, 3 to $12 \mathrm{ft}$ (1 to 3.5 $\mathrm{m})$

Qa2 Intermediate-age alluvial fan deposits (Holocene) - Lithologically similar to young alluvial fan (Qa1) deposits; partly cemented by calcite and gypsum; surfaces are more gravelly and often cut by arroyos as much as $10 \mathrm{ft}(3 \mathrm{~m})$ deep southwest of Little Colorado River. Surfaces are often covered by sand-sheet deposits too thin to show at map scale northeast of Little Colorado River. Unit commonly overlapped by young alluvial fan (Qa1) deposits near Little Colorado River and intertongues or overlap's valley-fill $(\mathrm{Qv})$, talus and rock fall (Qtr), and young and intermediate terrace-gravel (Qg1, Qg2) deposits southwest of Little Colorado River. Include abundant subrounded to subangular basalt clasts in southwest quarter of map area and abundant subangular chert clasts northeast of Little Colorado River. Support moderate growth of grass, sagebrush, and cactus southwest of Little Colorado River and little to no vegetation except grass northeast of Little Colorado River. Thickness, 6 to $50 \mathrm{ft}$ (2 to $15 \mathrm{~m}$ )

Qg2 Intermediate-age terrace-gravel deposits (Holocene)-Southwest of Little Colorado River: Gray and brown silt, sand, and gravel, mixed with black cinders; unconsolidated. Lithologically similar to young terrace-gravel (Qg1) deposits. Composed mainly of gray and brown siltstone and finegrained sandstone matrix mixed with subangular to rounded pebbles and boulders of local Permian limestone and Triassic sandstone. Include wellrounded basalt clasts derived from the San Francisco Volcanic Field. Locally intertongue with or inset into young and intermediate alluvial fan (Qa1, Qa2) deposits. Form terrace benches about 15 to $30 \mathrm{ft}(4.5$ to $9 \mathrm{~m}$ ) above modern streambeds and about 5 to $20 \mathrm{ft}$ (1.5 to $6 \mathrm{~m}$ ) above young terrace-gravel (Qg1) deposits. Support minor growth of high-desert shrubs and grass. Northeast and east of Little Colorado River: Form isolated deposits of gray and red silt, sand, and multi-colored, angular chert gravel. Form terrace benches 10 to $50 \mathrm{ft}$ ( 3 to $15 \mathrm{~m}$ ) above modern Little Colorado River. Thickness, 6 to $100 \mathrm{ft}$ ( 2 to $30 \mathrm{~m}$ )

Qf2 Intermediate-age flood-plain deposits (Holocene) - Gray-brown clay, silt, and fine-grained sand; weakly consolidated by clay and calcite cement. Lithologically similar to young flood-plain (Qf1) deposits but forms flat benches 10 to $15 \mathrm{ft}$ (3 to $4.5 \mathrm{~m}$ ) above stream-channel (Qs) of modern 
flood-plain (Qf) deposits along Little Colorado River. Subject to cut-bank and headward erosion by local stream channels. Overlapped by various accumulations of thin surficial (Qd, Qes, Qps, Qa1) deposits. Supports sparse to moderately thick growths of grass, camel thorn bush, tumble weed, salt bush, and other high-desert shrubs, as well as scattered cottonwood, salt cedar (tamarisk), and willow trees along Little Colorado River. Eolian-sand accumulations commonly cause temporary blockage of local runoff that forms ponded sediments (Qps) on flat flood-plain deposits (Qf2, Qf3). Subject to overbank flooding or local tributary channel erosion. Thickness unknown by may exceed $100 \mathrm{ft}(30 \mathrm{~m})$ in some areas; visible thickness, 10 to $30 \mathrm{ft}$ ( 3 to $9 \mathrm{~m}$ )

Qg3 Old terrace-gravel deposits (Holocene) - Gray and light-brown, unsorted, silt, sand, pebbles, cobbles, and boulders derived from local Permian and Triassic bedrock mixed with basalt clasts and cinders in abandoned channels eroded into the Kaibab Formation downstream of Grand Falls. Include abundant rounded and well-rounded clasts of quartzite and assorted metamorphic crystalline rocks derived from reworking of scattered Tertiary sediments south, southeast, and southwest of map; partly consolidated by calcite and gypsum cement. Lithologically similar to younger terracegravel (Qg1, Qg2) deposits but with less gravel and more silt and sand content. Forms terraces about 25 to $80 \mathrm{ft}$ ( 7.5 to $25 \mathrm{~m})$ above Little Colorado River and about 12 to $40 \mathrm{ft}$ (3.7 to $12 \mathrm{~m}$ ) above northeasterly tributary drainages to Little Colorado River in northwest corner of map. Unit commonly covered by thin deposits of wind-polished pebble and cobble clasts forming a thin veneer of desert pavement on surface upstream of Grand Falls. Thickness, 12 to $90 \mathrm{ft}$ (3.7 to $28 \mathrm{~m}$ )

Qf3 Old flood-plain deposits (Holocene) - Gray-brown clay, silt, and fine-grained sand; includes thin lenses of stream channel gravel and interbedded alluvial fan gravel along margins of unit. Lithologically similar to younger floodplain (Qf, Qf1, Qf2) deposits. Forms wide, flat benches, 15 to $35 \mathrm{ft}$ (4.5 to $10.5 \mathrm{~m}$ ) above stream-channel (Qs) and other flood-plain deposits of Little Colorado River area. Subject to cut-bank erosion and extensive headward erosion by local streams. Overlapped by thin surficial alluvial or eolian (Qd, Qes, Qdp, Qps, Qae, Qa1) deposits. Supports sparse to moderate growths of grass and a variety of small high-desert shrubs. Subject to local flooding where thin accumulations of ponded sediments (Qps) overlie old flood-plain (Qf3) deposits. Thickness unknown but may exceed 60 to $80 \mathrm{ft}$ (18 to $48 \mathrm{~m}$ ) in some areas; visible thickness, 10 to $45 \mathrm{ft}$ ( 3 to $14 \mathrm{~m}$ )

Qae Mixed alluvium and eolian deposits (Holocene) - Gray, light-red, and brown clay, silt, fine- to coarse-grained sand, and black cinder ash interbedded with lenses or beds of gravel. Include white angular chert fragments locally derived from the Kaibab Formation southwest of Little Colorado River, and white, gray, brown, and red chert fragments derived from the Chinle Formation northeast and east of Little Colorado River. Deposits accumulated by combination of alluvial and eolian processes resulting in an interbedded sequence of mixed mud, silt, sand, cinder, and gravel. Unit subject to sheet-wash erosion during wet conditions and often covered by 
windblown sand and cinder accumulations in dry conditions. Commonly occupies broad, gently sloping, flatland topography. Support light to moderate growths of grass, cactus, and high-desert low shrubs. Thickness, 2 to $20 \mathrm{ft}(0.6$ to $6 \mathrm{~m})$

Qa3 Old alluvial fan deposits (Holocene and Pleistocene(?)) - Gray and light-brown, silt, sand, and gravel. Lithologically similar to young and intermediate alluvial fan (Qa1, Qa2) deposits with minor cinder deposits. Unit is extensively eroded by arroyos or local headward erosion of nearby drainages in northeast quarter of map; partly consolidated by clay and calcite cement. Surface has thin calcrete soil development on larger deposits. Supports moderate growth of grass, sagebrush, cactus, and low desert shrubs. Thickness, 5 to $35 \mathrm{ft}$ (1.5 to $11 \mathrm{~m})$

Qv Valley-fill deposits (Holocene and Pleistocene(?)) - Gray and light-brown silt, sand, black cinders, and gray lenses of gravel; partly consolidated by gypsum and calcite cement west and southwest of Little Colorado River. Include minor rounded clasts of limestone and sandstone, subrounded to angular chert, and basalt gravel southwest of Little Colorado River. Include abundant reworked sediment and fragments from Meteor Crater impact debris $(\mathrm{Qmc})$ near Meteor Crater. Intertongues with or overlapped by Holocene alluvial fan (Qa1, Qa2) deposits and Holocene terrace-gravel (Qg1, Qg2) deposits. Commonly reflects low-energy and low-gradient shallow valley drainages. Subject to sheet-wash flooding and temporary ponding owing to thick growths of sagebrush, grass, and cactus. Thickness, 3 to $20 \mathrm{ft}$ ( 1 to $6 \mathrm{~m})$

Qtr Talus and rock-fall deposits (Holocene and Pleistocene) - Brown, gray, slopeforming, unsorted mixture of mud, silt, sand, pebbles, cobbles, and small to large angular boulders. Form talus debris slopes in steep-walled canyon of Little Colorado River, Canyon Diablo, and below Tertiary basalt flows of unnamed butte in southwest corner of map. Include individual car- and house-size boulders. Clasts are angular, unsorted, and partly cemented by calcium carbonate. Gradational contact with other Holocene surficial (QI, Qa1, Qa2, Qg1, Qg2, Qv) deposits. Subject to extensive sheet-wash erosion, flash-flood debris flows, and arroyo erosion. Only thick or extensive deposits shown. Thickness, 3 to $35 \mathrm{ft}$ ( 1 to $11 \mathrm{~m}$ )

Landslide deposits (Holocene and Pleistocene) - Unconsolidated to partly consolidated masses of unsorted breccia rock debris. Include blocks of strata that have detached from parent source, rotated backward and slid down slope as loose masses of brecciated deformed strata. Deposits are common below unnamed butte in southwest corner of map. Locally includes talus and rockfall debris adjacent to and below landslide masses. Some landslide blocks may become unstable with minor movement in wet conditions. Small landslide masses in tributary canyon drainages, such as Canyon Diablo, have caused temporary blockage of drainage. Thickness of landslides, 10 to $120 \mathrm{ft}$ ( 3 to $36 \mathrm{~m}$ )

Qmc Meteor Crater impact debris (Pleistocene) - Gray, light-red, unsorted, angular fragments of meteor impact debris derived from Meteor Crater (fig. 2, map sheet) approximately 50,000 years ago (Kargel, 1998). Includes unsorted, 
angular, sand and small breccia debris with some blocks as large as $100 \mathrm{ft}$ (30 m) across (Shoemaker and Kieffer, 1974). Impact debris includes highly mixed fragments of Coconino Sandstone, Toroweap Formation, Kaibab Formation, and Moenkopi Formation. Mixed breccia along walls of crater slumps back toward center of crater (not mapped). Thickness, 3 to 50 $\mathrm{ft}$ (1 to $15 \mathrm{~m})$

Qg4 Older terrace-gravel deposits (Pleistocene) - Gray and light-brown, poorly sorted clay, silt, sand, gravel, pebbles, cobbles, and boulders; weakly cemented by clay and calcite. Include rounded and well-rounded quartzite and assorted metamorphic crystalline clasts derived from reworking of Tertiary gravel sediments south and southeast of map area. Also include well-rounded white chert, gray limestone, and red sandstone clasts derived from the Kaibab and Moenkopi Formations and subrounded to rounded basalt clast from San Francisco Volcanic Field. Form terrace deposits in abandoned Little Colorado River channels eroded into Kaibab Formation downstream of Grand Falls and in abandoned tributary channels southeast of Grand Falls that form inverted topography outcrops where not covered by basalt flows. Thickness, 6 to $80 \mathrm{ft}$ ( 2 to $25 \mathrm{~m}$ )

Qg5 Young Little Colorado River deposits (Pleistocene) - Gray and light-brown, poorly sorted silt, sand, gravel, pebbles, cobbles, and boulders; weakly consolidated by calcite and clay cement. Pebbles and cobbles are mostly small, well-rounded, black chert, gray, light-red, and brown quartzite, and yellow to white quartz. Include well-rounded, reddish-brown quartzite cobbles. Pebbles and cobbles weather out as lag gravel that forms armored surface that helps preserve underlying fine-grained silt and sand deposits. Extensively eroded and gullied; fills Little Colorado River channel eroded into lower strata of Moenkopi Formation and upper strata of Kaibab Formation downstream (west) of Grand Falls about 200 to $250 \mathrm{ft}$ (60 to 76 m) above modern Little Colorado River canyon. Unit partly covered by eolian cinder (Qsc, Qdc1) deposits. Thickness, 20 to $80 \mathrm{ft}$ (6 to $24 \mathrm{~m}$ )

Qg6 Intermediate-age Little Colorado River deposits (Pleistocene) - Gray to lightbrown, poorly sorted, weakly consolidated sand and arkosic gravel with gray, white, red, brown, and black quartzite and chert pebbles, cobbles, and small boulders $(0.5$ in to $1 \mathrm{ft}$ [ 1.5 to $30 \mathrm{~cm}$ ] in diameter). Largest boulders are mostly subrounded clasts derived from the Kaibab Formation in deposits southwest and west of Grand Falls. Lag gravel forms gray armored cover on red hills of Moenkopi Formation southwest and west of Grand Falls that are about 280 to $300 \mathrm{ft}(85$ to $92 \mathrm{~m}$ ) above modern Little Colorado River canyon. Deposits have similar protective lag gravel on ridge northeast of Grand Falls about $140 \mathrm{ft}$ (43 m) above Little Colorado River floodplain; unit is about $100 \mathrm{ft}(30 \mathrm{~m})$ below nearby highest Little Colorado River deposits (Qg7) northeast of Grand Falls. Unit forms inverted topography of Little Colorado channel about $2 \mathrm{mi}(3 \mathrm{~km})$ northeast of Grand Falls. Thickness, $75 \mathrm{ft}$ (23 m)

Qg7 Old Little Colorado River deposits (Pleistocene) - Light-red, gray, and brown interbedded siltstone, sandstone, arkosic gravel, and lenticular conglomerate similar to intermediate-age Little Colorado River (Qg6) 
deposits. Unit fills Little Colorado River channel eroded into upper Moenkopi Formation. Pebbles and cobbles composed mostly of wellrounded, brown, yellow-white, red-brown, gray and black quartzite and chert, and minor clasts of granite and metamorphic rocks derived from older Tertiary gravel deposits southeast of the map area; include abundant gray, subrounded limestone clasts derived from Kaibab Formation and red sandstone clasts derived from Moenkopi Formation. Unit forms highest Little Colorado River gravel deposits in map area that are likely Pleistocene age based on similar deposits northwest of map within the Cameron $30^{\prime}$ x $60^{\prime}$ quadrangle (Billingsley and others, 2007). Thickness, 3 to $25 \mathrm{ft}$ ( 1 to $7.6 \mathrm{~m})$ or more

\section{VOLCANIC ROCKS}

Volcanic rocks of the San Francisco Volcanic Field (Pleistocene)—Modified from Moore and Wolfe (1976). For a complete history of magnetic polarity age determinations, analytical data, and classification of basalt types in this map area, see Ulrich and Bailey (1987)

\section{Qbm1}

Qbm2
The Sproul basalt flow of Merriam Crater (Pleistocene) - Herein informally named from a small volcanic crater called "The Sproul" on the west side of Merriam Crater, $2 \mathrm{mi} \mathrm{(3.2} \mathrm{km)} \mathrm{west} \mathrm{of} \mathrm{map} \mathrm{edge} \mathrm{(T.} 23$ N., R. 10 E., sec. 36, USGS 7.5' Merriam Crater quadrangle, 1969). Dark-gray alkali olivine basalt. Contains scattered phenocrysts of olivine, clinopyroxene, and rare plagioclase in groundmass of similar minerals and opaque oxides. Basalt flow originates from The Sproul, a black basalt vent on west side of Merriam Crater $4 \mathrm{mi}(6.5 \mathrm{~km})$ southwest of mapped flow at northwest edge of map. This flow traveled northeast to Grand Falls and appears to merge with or overflow the basalt flow of Merriam Crater $(\mathrm{Qbm})$ about $1 \mathrm{mi}(1.6 \mathrm{~km})$ south of Grand Falls. This flow or the basalt flow from Merriam Crater (Qbm), or both (?), formed a basalt dam across the Little Colorado River canyon resulting in the development of Grand Falls (fig. 3, map sheet). Basalt flow also traveled down Little Colorado River canyon approximately $21 \mathrm{mi}(33.5 \mathrm{~km})$ downstream of Grand Falls. Age of the basalt dam at Grand Falls is 19.6 $\pm 1.2 \mathrm{ka}$ (Esser, 2003; Duffield and others, 2006).

A similar age basalt flow (Qbm2) from two vents on the east side of Merriam Crater merged and traveled northeast along and over the basalt flow of Merriam Crater (Qbm). Both The Sproul and the two east vent basalt flows appear to have erupted simultaneously shortly after development of the larger Merriam Crater pyroclastic cone. Thickness, 6 to $130 \mathrm{ft}$ ( 2 to $40 \mathrm{~m})$

East vent basalt flow of Merriam Crater (Pleistocene) - Herein informally named from two unnamed vents on the east side of Merriam Crater, $2 \mathrm{mi}$ $(3.2 \mathrm{~km}$ ) west of map edge (T. $23 \mathrm{~N}$, R. $10 \mathrm{E}$, sec. 36, USGS 7.5' Merriam Crater quadrangle, 1969). Dark-gray and black porphyritic and aphyric, clinopyroxene-olivine and alkali-olivine basalt. Two flows came from two vents that appear to have erupted simultaneously on the east side of Merriam Crater (east vent) that traveled northeast and merged into one 
flow onto the basalt flow of Merriam Crater (Qbm) and appears to have stopped $1 \mathrm{mi}(1.6 \mathrm{~km})$ south of Grand Falls. Basalt flow of Merriam Crater (Qbm) is locally covered by thicker deposits of alluvium and eolian cinder deposits, suggesting that it is older than The Sproul or east vent flow. Thickness, 3 to $65 \mathrm{ft}$ ( 1 to $20 \mathrm{~m}$ )

Basalt flow of Merriam Crater (Pleistocene)-Herein informally named from Merriam Crater, $2 \mathrm{mi}(3.2 \mathrm{~km}$ ) west of map edge (T. 23 N., R. 10 E., sec. 36, USGS 7.5' Merriam Crater quadrangle, 1969). Dark-gray to black olivine basalt. Basalt flow is overlain by approximately $1,000 \mathrm{ft}(300 \mathrm{~m})$ of red pyroclastic deposits that formed Merriam Crater cinder cone $2 \mathrm{mi}$ (3 $\mathrm{km}$ ) west of northwest map edge. Basalt flowed northeast toward Little Colorado River and appears to have stopped $1 \mathrm{mi}(1.6 \mathrm{~km})$ south of Grand Falls but may have reached the Little Colorado River and either merges with or is covered by The Sproul basalt flow of Merriam Crater (Qbm1). Flow surface near Merriam Crater is mostly covered by mixed alluvium and eolian cinder (Qae, Qsc, Qdc1) deposits. Thickness, 15 to $30 \mathrm{ft}$ (4.5 to $9 \mathrm{~m}$ )

Qbr Basalt flow of Roden Crater (Pleistocene)-Herein informally named from Roden Crater, $0.5 \mathrm{mi}(0.8 \mathrm{~km})$ west of map edge (T. 24 N., R. 11 E., sec. 31, USGS 7.5' Roden Crater quadrangle, 1969). Dark-gray to black olivine basalt. Contains phenocrysts of olivine, clinopyroxene, and some plagioclase in groundmass of the same minerals plus opaque oxides. Roden Crater is a 500-ft-high (153-m-high) red pyroclastic cone that formed over the associated basalt flow from Roden Crater vent. The basalt flowed over $1.5 \mathrm{mi}(2.5 \mathrm{~km})$ from Roden Crater northeastward over sandstone strata of the Moenkopi Formation. Flow appears to have stopped near and slightly below intermediate-age Little Colorado River deposits (Qg6) southwest of Little Colorado River canyon, downstream of Grand Falls. Thickness, 100 $\mathrm{ft}(30 \mathrm{~m})$

Qp Pyroclastic deposits, undivided (Pleistocene) - Red or black, massivebedded, air-fall cinder, volcanic bomb, and splatter deposits that overlie basalt flows from associated eruptive vent area. Unit is matrix free, except for locally reworked zone in upper $3 \mathrm{ft}(1 \mathrm{~m})$ or more of unit. Contains xenoliths of red, white, or gray limestone and sandstone and white chert fragments. Unit overlies locally associated basalt flows along west edge of map and is partly overlapped by basalt flows $(\mathrm{Qb})$ at one location along east edge of map. Unit does not include eolian cinder sand-sheet (Qsc) or cinder-dune (Qdc1, Qdc2) deposits, but may intertongue with eruptive air fall eolian deposits. Thickness, 10 to $15 \mathrm{ft}$ ( 3 to $5 \mathrm{~m}$ ) plagioclase-phyric basalt with abundant 1- to 3 -cm plagioclase laths in groundmass of olivine, clinopyroxene, plagioclase, and magnetite. Includes basalt flows from Merrill Crater, South Sheba Crater, and an unnamed crater (elevation 5,397) just west of map edge. K-Ar age of various flows west of map are $0.22 \pm 0.05 \mathrm{Ma}, 0.46 \pm 0.05 \mathrm{Ma}, 0.66 \pm 0.11 \mathrm{Ma}, 0.74 \pm 0.08$ $\mathrm{Ma}$, and $0.77 \pm 0.04 \mathrm{Ma}$ (Ulrich and Bailey, 1987). Basalt flows appear to merge or overlap, which makes identifying the source eruptive vent(s) 
Qbw

$\mathrm{Tb}$

Kco

Kcp

difficult. One or more of these basalt flows reached the Little Colorado River and formed the basalt dam on the east side of Tolchico Anticline $\left(175 \mathrm{Ka},{ }^{40} \mathrm{Ar} /{ }^{39} \mathrm{Ar}\right.$; Esser, 2003). Thickness, 15 to $250 \mathrm{ft}$ (4.5 to $\left.76 \mathrm{~m}\right)$

Basalt flow of Woodhouse age (Pleistocene) - Informally named by Ulrich and Bailey, 1987). Dark-gray, plagioclase-phyric and porphyritic basalt of similar composition to pyroclastic (Qp) deposits. Weathers yellow or brown. Surfaces are subdued and slightly eroded and gullied. K-Ar age of various flows outside of map area, $0.83 \pm 0.04 \mathrm{Ma}, 1.04 \pm 0.04 \mathrm{Ma}$, $1.20 \pm 0.05 \mathrm{Ma}$, and 1.38 $\pm 1.01 \mathrm{Ma}$ (Ulrich and Bailey, 1987; Wolfe and others, 1987). Flows generally followed older drainages and now represent inverted topography above present drainages. Thickness, 15 to $160 \mathrm{ft}$ (4.5 to $48 \mathrm{~m}$ )

Tertiary Basalt flow (Miocene) - Dark-gray to black plagioclase-phyric basalt; surface weathers smooth and is locally dissected. Contains scattered to abundant tabular plagioclase phenocrysts as large as $1 \mathrm{~cm}$ in diameter and includes abundant olivine microphenocrysts in feldspathic groundmass with granular to ophitic intergrowth of brown pyroxene and plagioclase. KAr age, $2.43 \pm 0.32 \mathrm{Ma}$ (Ulrich and Bailey, 1987). Forms basalt caprock in drainage eroded into the Shinarump Member of the Chinle Formation that flowed northeastward from basalt flows of Anderson Mesa southwest of map. Basalt flow now forms inverted valley ridge on unnamed butte in southwest corner of map. Thickness 20 to $30 \mathrm{ft}$ (6 to $9 \mathrm{~m}$ )

\section{SEDIMENTARY ROCKS}

Chinle Formation (Upper Triassic) - Consists of the Owl Rock, the Petrified Forest, and the Shinarump Members (Repenning and others, 1969)

Owl Rock Member (Upper Triassic) - Gray-red and light-purple, slope- and ledge-forming, nodular limestone interbedded with purple, light-blue, and light-red calcareous claystone, siltstone, and sandstone. Limestone beds that are gray, cherty, lenticular, silty, irregularly bedded, and 1 to $5 \mathrm{ft}(0.5$ to $1.5 \mathrm{~m}$ ) thick extend laterally several miles northwest and southeast of map area. Unit thickens northwest and southeast of map to as much as 300 $\mathrm{ft}(92 \mathrm{~m}$ ); approximately 30 to $50 \mathrm{ft}$ (9 to $15 \mathrm{~m}$ ) has been removed by modern erosion at Newberry Mesa, northeast corner of map. Consists of as many as 6 to 7 resistant limestone ledges in northeast corner of map. Unit contains abundant mud pellets and silicified clay and concretionary chert nodules. Contact with underlying Petrified Forest Member ( $\mathrm{kcp}$ ) is gradational and arbitrarily marked at lowest limestone bed or at nodular calcareous gray-white siltstone in slope below lowest limestone bed. Thickness, 130 (40 m)

Petrified Forest Member (Upper Triassic) - Purple, blue, light-red, redpurple, and gray-blue, slope-forming mudstone, siltstone, and interbedded white, coarse-grained lenticular sandstone. Includes large-scale erosion channel structures and large-scale low-angle trough crossbedding. Petrified logs and wood fragments are common in white or yellow-white sandstone beds in lower part that may be within upper part of underlying Shinarump Member (KCs). Contact with Shinarump Member marked at lithologic and 
topographic change from sloping multicolored mudstone of Petrified Forest Member to coarse-grained, white sandstone slopes and ledges of Shinarump Member. Weathers into rounded hills or slopes with rough, puffy, popcorn surface owing to swelling of clay content when wet; mostly covered by young surficial alluvium and eolian deposits in valley drainages and by older alluvial and eolian deposits on some ridges. Thickness, 400 to $450 \mathrm{ft}$ (122 to $137 \mathrm{~m})$

Shinarump Member (Upper Triassic) - White and light-brown, ledge- and slope-forming, coarse-grained sandstone and conglomeratic sandstone. Includes low-angle crossbedded white sandstone interbedded with purple, light-red, and blue poorly sorted siltstone and mudstone in upper part that may be lower part of Petrified Forest Member ( $\mathrm{k} c \mathrm{p})$. Gradational contact with overlying Petrified Forest Member. Lithology is highly variable in lateral and vertical distribution but relatively homogeneous from a regional viewpoint; unit consists of about 75 percent sandstone, 20 percent conglomerate, and 5 percent mudstone (Repenning and others, 1969). Pebbles are generally black, brown, and light-red, well-rounded quartzite and a black chert composition. Multicolored petrified logs and wood fragments are generally scattered throughout unit. Unit is locally absent northeast of Little Colorado River at some locations; commonly covered by surficial eolian deposits. Unconformably overlies red siltstone and sandstone of upper Moenkopi Formation ( $\mathrm{kmhm})$. Thickness, 0 to $40 \mathrm{ft}$ ( 0 to $12 \mathrm{~m}$ )

Moenkopi Formation (Middle(?) and Lower Triassic) - Consists of, in descending order, the Holbrook Sandstone and Moqui Members, undivided, the lower massive sandstone member, and the Wupatki Member as defined by McKee (1954). Overall thickness before Cenozoic erosion, $220 \mathrm{ft}(67 \mathrm{~m})$

kmhm Holbrook and Moqui Members, undivided (Middle(?) and Lower Triassic)—Reddish-brown, slope-forming, alternating sequence of claystone, siltstone, and sandstone (Hagar, 1922; McKee, 1954). Includes large- to medium-scale trough crossbedding and abundant cusp-type ripple marks that testify to fluvial origin. Includes isolated or scattered meander channels of red-brown elongated resistant sandstone ridges of Holbrook Member that overlie red sandstone and siltstone beds of slope-forming Moqui Member; collectively mapped as undivided. Fossil casts of reptile tracks are often preserved on bottom surfaces of sandstone beds. Include interbedded, thin-bedded limestone, conglomeratic sandstone lenses, gypsiferous siltstone, and numerous gypsum veins in Moqui Member. Thickness, 80 to $120 \mathrm{ft}$ ( 25 to $37 \mathrm{~m}$ )

kmss Lower massive sandstone member (Lower Triassic) - Light-red and lightbrown, cliff-forming, crossbedded, fine-grained calcareous siltstone and sandstone. Forms prominent isolated ledges or sandstone knobs 10 to $20 \mathrm{ft}$ ( 9 to $4.5 \mathrm{~m}$ ) thick in northeast quarter of map between Meteor Crater and Grand Falls. Salt weathering of sandstone forms pitted and fluted weathered surface in well-exposed outcrops. Unit correlates to the Shnabkaib Member of the Moenkopi Formation in northwestern Arizona 
(Billingsley and others, 2007). Minor erosional contact with underlying Wupatki Member (Kmw) marked at base sandstone cliff. Unconformably overlies the Kaibab Formation, where underlying Wupatki Member is absent or too thin to show at map scale. This contact forms the regional Permian-Triassic boundary. Thickness, 10 to $20 \mathrm{ft}$ (9 to $4.5 \mathrm{~m}$ )

Wupatki Member (Lower Triassic) — Red and red-brown, slope-forming, thin-bedded siltstone and sandstone and interbedded crumbly red-brown mudstone. Thin, flat sandstone beds ( 1 to $2 \mathrm{ft}$ [0.4 to $0.6 \mathrm{~m}]$ ) form resistant ledges within slopes in northwest quarter of map. Bedding surfaces often contain small-scale ripple marks or rain-drop impressions. Unit gradually thins east and southeast across map. Unconformably overlies Kaibab Formation and forms the regional Permian-Triassic boundary; the contact is generally of low relief, less than $5 \mathrm{ft}(1.5 \mathrm{~m})$. Thickness, 20 to $35 \mathrm{ft}$ (6 to $10 \mathrm{~m}$ )

Pk Kaibab Formation (Cisuralian) — Includes, in descending order, Harrisburg and Fossil Mountain Members as defined by Sorauf and Billingsley (1991). Members are difficult to separate because of similar lithology owing to facies changes of both units that collectively form a gray to light-brown, cliff-forming, calcareous sandstone and sandy limestone. Please note that Lower Permian is now referred to as Cirsuralian

Harrisburg Member: Red-gray to brownish-gray, slope-forming gypsum, siltstone, sandstone, and thin-bedded limestone. Includes yellowish-gray fossiliferous sandy limestone at top of unit that is largely removed by modern erosion from parts of map area. Forms surface bedrock throughout map area. Contact with underlying Fossil Mountain Member is gradational and placed at topographic break between reddish-gray, slopeand ledge-forming sandy limestone and sandstone sequence of Harrisburg Member and underlying gray to light-brown, cliff-forming cherty limestone of Fossil Mountain Member. Unit gradually thins from west to east and undergoes a shoreward (eastward) facies change from limestone and sandy limestone to calcareous sandstone and sandstone. Thickness, 80 to $120 \mathrm{ft}$ (25 to $37 \mathrm{~m}$ ).

Fossil Mountain Member: Light-gray, cliff-forming, fine- to medium-grained, thin- to medium-bedded (1 to $6 \mathrm{ft}[0.3$ to $2 \mathrm{~m}]$ ), fossiliferous, cherty, sandy limestone and minor dolomite. Weathers dark gray or brown, often stained by black manganese oxide. Unit characterized by gray to white fossiliferous chert nodules and thin chert breccia beds. Chert breccia beds are less than $3 \mathrm{ft}(1 \mathrm{~m})$ thick and commonly mark uppermost part of Fossil Mountain Member. Unit gradually thins from west to east and undergoes a shoreward (eastward) facies change from sandy limestone to calcareous sandstone, similar in texture, composition, and appearance to overlying Harrisburg Member. Typically forms cliff or series of ledges in lower half of tributary canyons to Little Colorado River and Little Colorado River canyon below Grand Falls and at Tolchico canyon and Meteor Crater. Unconformable contact with underlying Toroweap Formation attributed mostly to shallow channel erosion into similar color sandstone of the Toroweap Formation in Meteor Crater and 
below Grand Falls; average erosional relief, about $10 \mathrm{ft}(3 \mathrm{~m})$. Thickness, $180 \mathrm{ft}(55 \mathrm{~m})$

Pt Toroweap Formation, undivided (Cirsuralian) — White, low-angle, cliffforming, crossbedded sandstone in Meteor Crater and downstream of Grand Falls. Unit may be present in bottoms of some tributary canyons such as Canyon Diablo, Padre Canyon, and others but is too thin to show or is difficult to distinguish from overlying Kaibab Formation. Unit gradually thins southeast in the subsurface of the map area where drill holes near Leupp, Arizona, indicate that only 20 to $30 \mathrm{ft}$ ( 6 to $9 \mathrm{~m}$ ) of Toroweap Formation is present (Bills and others, 2005) and about the same amount is present in Meteor Crater (Shoemaker and Kieffer, 1974). In the subsurface, the Toroweap Formation has a sharp unconformable contact with underlying Coconino Sandstone based on exposures northwest of map area near Cameron, Arizona (Billingsley and others, 2007). Thickness northwest to southeast, 30 to $20 \mathrm{ft}$ ( 9 to $6 \mathrm{~m}$ )

\section{References Cited}

Billingsley, G.H., 1987, Geology and geomorphology of the southwestern Moenkopi Plateau and southern Ward Terrace, Arizona: U.S. Geological Survey Bulletin 1672, 18 p.

Billingsley, G.H., Block, Debra, and Redsteer, M.H., 2013, Geologic map of the Winslow 30' x 60' quadrangle, Coconino and Navajo Counties, northern Arizona: U.S. Geological Survey Scientific Investigations Map 3247, scale 1:50,000, 3 sheets, pamphlet 41 p., available at http://pubs.usgs.gov/sim/3247/.

Billingsley, G.H., Priest, S.S., and Felger, T.J., 2007, Geologic map of the Cameron 30' x 60' quadrangle, Coconino County, northern Arizona: U.S. Geological Survey Scientific Investigations Map 2977, scale 1:100,000, 1 sheet, pamphlet 33 p., available at http://pubs.usgs.gov/sim/2007/2977/.

Billingsley, G.H., and Wellmeyer, J.L., 2003, Geologic map of the Mount Trumbull 30' x 60' quadrangle, Mohave and Coconino Counties, northwestern Arizona: U.S. Geological Survey Geologic Investigations Map I-2766, scale 1:100,000, pamphlet 36 p., available at http://pubs.usgs.gov/imap/i2766/.

Billingsley, G.H., and Workman, J.B., 2000, Geologic map of the Littlefield 30' x 60' quadrangle, Mohave County, northwestern Arizona: U.S. Geological Survey Geologic Investigations Series I2628, scale 1:100,000, pamphlet 25 p., available at http://geopubs.wr.usgs.gov/I-map/i2628/.

Bills, D.J., Flynn, M.E., and Monroe, S.A., 2005, Hydrology of the Coconino Plateau and adjacent areas, Coconino and Yavapai Counties, Arizona: U.S. Geological Survey Scientific Investigations Report 2005-5222, 4 plates, $101 \mathrm{p}$.

Blakey, R.C., 1990, Stratigraphy and geologic history of Pennsylvanian and Permian rocks, Mogollon Rim region, central Arizona and vicinity: Geological Society of America Bulletin v. 102, p. 1189-1217.

Blakey, R.C., 1994, Paleogeographic and tectonic controls on some Lower and Middle Jurassic erg deposits, Colorado Plateau, in Caputo, M.V., Peterson, J.A., and Franczyk, K.J., eds., Mesozoic systems of the Rocky Mountain region, USA: Denver, Colo., Rocky Mountain Section of the Society of Sedimentary Geology Meeting, p. 273-298. 
Blakey, R.C., 1996, Permian eolian deposits, sequences, and sequence boundaries, Colorado Plateau, in Longman, M.W., and Sonnenfeld, M.D., eds., Paleozoic systems of the Rocky Mountain region: Denver, Colo., Society of Sedimentary Geology (SEPM), Rocky Mountain Section, p. 405-426.

Blakey R.C., and Ranney, Wayne, 2008, Ancient Landscapes of the Colorado Plateau: Grand Canyon, Ariz., Grand Canyon Association, 156 p.

Block, Debra, and Redsteer, M.H., 2011, A dryland river transformed - the Little Colorado, 19362010: U.S. Geological Survey Fact Sheet 2011-3099, 4 p., available at http://pubs.usgs.gov/fs/2011/3099/.

Cooley, M.E., Harshbarger, J.W., Akers, J.P., and Hardt, W.F., 1969, Regional hydrogeology of the Navajo and Hopi Indian Reservations, Arizona, New Mexico, and Utah: U.S. Geological Survey Professional Paper 521-A, plate 1 (sheet 2 of 9), p. A1-A61.

Damon, P.E., Shafiqullah, M., and Leventhal, J.S., 1974, K-Ar chronology for the San Francisco Volcanic Field and rate of erosion of the Little Colorado River, in Karlstrom, T.N.V., Swann, G.A., and Eastwood, R.L., eds., Geology of northern Arizona with notes on archaeology and paleoclimate, Part 1, Regional Studies: Flagstaff, Ariz., Geological Society of America Rocky Mountain Section Meeting, p. 221-235.

Duffield, W.A., Riggs, N.R., Kaufman, Darrell, Champion, Duane, Fenton, Cassandra, Forman, Steven, McIntosh, William, Hereford, Richard, Plescia, Jeffery, and Ort, Michael, 2006, Multiple constraints on the age of a Late Pleistocene lava dam across the Little Colorado River at Grand Falls, Arizona: Geological Society of America Bulletin, v. 118, no. 3/4, p. 421-429.

Esser, R.P., 2003, ${ }^{40} \mathrm{Ar} /{ }^{39} \mathrm{Ar}$ Geochronology results from volcanic rocks from Grand Falls, Arizona: Socorro, New Mexico Bureau of Mines and Mineral Resources, New Mexico Geochronological Research Laboratory, Internal Report NMGRL-IR-227, 5 p.

Hager, Dorsey, 1922, Oil possibilities of the Holbrook area in northeast Arizona: Mining and Oil Bulletin, v. 8, no. 1, p.23-47; no. 2, p. 71-74; no. 3, p. 135-140.

Hanson, S.L., 2009, Evaluation of potential source vents for the Grand Falls lava flow, San Francisco Volcanic Field, northern Arizona: Geological Society of America Abstracts with Programs, v. 41, no. 7, p. 644.

Hanson, S.L., Duffield, Wendell, and Plescia, Jeffery, 2008, Quaternary volcanism in the San Francisco Volcanic Field; recent basaltic eruptions that profoundly impacted the northern Arizona landscape and disrupted the lives of nearby residents, in Duebendorfer, E.M., and Smith, E.I., eds., Field guide to plutons, volcanoes, faults, reefs, dinosaurs, and possible glaciation in selected areas of Arizona, California, and Nevada: Geological Society of America Field Guide 11, p. 173-186.

Hooten, J.A., Ort, M.H., and Elston, M.D., 2001, Origin of cinders in Wupatki National Monument: Tucson, Ariz., Desert Archaeology, Inc., Technical Report No. 2001-12, 20 p.

Huntoon, P.W., 2003, Post-Precambrian tectonism in the Grand Canyon region, in Beus, S.S. and Morales, Michael, eds., Grand Canyon Geology (2nd ed.): New York, Oxford University Press, p. 222-259.

Kargel, J.S., 1998, Meteor Crater, Arizona; geology and cultural history, in Duebendorfer, E.M., ed., Geologic excursions in northern and central Arizona: Geological Society of America field trip guidebook, Rocky Mountain Section Meeting, Northern Arizona University, Flagstaff, Ariz., p. 175.

Lucchitta, Ivo, 1990, History of the Grand Canyon and of the Colorado River in Arizona, in Beus, S.S., and Morales, Michael, eds., Geology of the Grand Canyon: New York, Oxford University Press, and Flagstaff, Ariz., the Museum of Northern Arizona Press, p. 311-332. 
McKee, E.D., 1954, Stratigraphy and history of the Moenkopi Formation of Triassic age: Geological Society of America Memoir, 61, 133 p.

Moore, R.B., and Wolfe, E.W., 1976, Geologic map of the eastern San Francisco Volcanic Field, Arizona: U.S. Geological Survey Miscellaneous Investigations Series I-953, scale 1:50,000.

Moore, R.B., and Wolfe, E.W., 1987, Geologic map of the east part of the San Francisco Volcanic Field, north-central Arizona: U.S. Geological Survey Miscellaneous Field Studies Map MF-1960, scale 1:50,000.

Moore, R.B., Wolfe, E.W., and Ulrich, G.E., 1974, Geology of the eastern and northern parts of the San Francisco Volcanic Field, Arizona, in Karlstrom T.N.V., Swann, G.A., and Eastwood, R.L., eds., Geology of northern Arizona with notes on archaeology and paleoclimate, Part 11, Area studies and field guides: Geological Society of America Rocky Mountain Section Meeting, Flagstaff, Ariz., p. 465-494.

Ranney, Wayne, 2005, Carving Grand Canyon, evidence, theories, and mystery: Grand Canyon, Ariz., Grand Canyon Association, 160 p.

Repenning, C.A., Cooley, M.E., and Akers, J.P., 1969, Stratigraphy of the Chinle and Moenkopi Formations, Navajo and Hopi Indian Reservations, Arizona, New Mexico, and Utah: U.S. Geological Professional Paper 521-B, 34 p.

Richard, S.M., Reynolds, S.J., Spencer, J.E., Pearthree, P.A., comps., 2000, Geologic map of Arizona: Tucson, Ariz., Arizona Geological Survey Map, M-35, scale 1:1,000,000.

Shoemaker, E.M., and Kieffer, S.W., 1974, Guidebook to the geology of Meteor Crater, Arizona: Tempe, Arizona State University, Center for Meteorite Studies, 37th annual meeting of the Meteoritical Society, no. 17, 66 p.

Sorauf, J.E., and Billingsley, G.H., 1991, Members of the Toroweap and Kaibab Formation, lower Permian, northern Arizona and southwestern Utah: Mountain Geologists, v. 28, no. 1, p. 9-24.

Stanesco, J.D., 1991, Sedimentology and cyclicity in the lower De Chelly Sandstone on the Defiance Plateau, eastern Arizona: Mountain Geologists, v. 28, no. 4, p. 1-11.

Ulrich, G.E., and Bailey, N.G., 1987, Geologic map of the SP Mountain part of the San Francisco Volcanic Field, north-central Arizona: U.S. Geological Survey Miscellaneous Field Studies Map MF-1956, 2 sheets, scale 1:24,000.

Ulrich, G.E., Billingsley, G.H., Hereford, Richard, Wolfe, E.W., Nealey, L.D., and Sutton, R.L., 1984, Map showing geology, structure, and uranium deposits of the Flagstaff $1^{\circ} \times 2^{\circ}$ quadrangle, Arizona: U.S. Geological Survey Miscellaneous Investigations Series I-1446, scale 1:250,000.

Weir, G.W., Ulrich, G.E., and Nealey, D.L., 1989, Geologic map of the Sedona 30' x 60' quadrangle, Yavapai and Coconino Counties, Arizona: U.S. Geological Survey Miscellaneous Investigations Series I-1896, scale 1:100,000.

Wilson, E.D., Moore, R.T., and Cooper, J.R., 1969, Geological map of the State of Arizona: Tucson, Ariz., Arizona Bureau of Mines and U.S. Geological Survey, scale 1:500,000.

Wolfe, E.W., Ulrich, G.E., and Newhall, C.G., 1987, Geologic map of the northwest part of the San Francisco Volcanic Field, north-central Arizona: U.S. Geological Survey Miscellaneous Field Studies Map MF-1957, scale 1:50,000, 2 sheets. 